Sains Malaysiana 49(5)(2020): 1089-1096

http://dx.doi.org/10.17576/jsm-2020-4905-13

\title{
Prevalence of Depression and Associated Factors among Tuberculosis Patients in Primary Care in the District of Kuching, Sarawak
}

(Prevalens Depresi dan Faktor Berkaitan dalam Kalangan Pesakit Tuberkulosis di Pusat Jagaan Primer di Daerah Kuching, Sarawak)

\author{
Tiong Chong Ying, NoOR AZAH ABD AZIZ*, RAHMAH KAMALUdDin \& ZUHRA HAMZAH
}

\begin{abstract}
Depression in tuberculosis (TB) increases the risks of adverse health outcomes. However, little is known about depression in tuberculosis patients in Malaysia. The aim of this study was to determine the prevalence and associated factors of depression in tuberculosis patients in primary care clinics. A cross-sectional study was adapted for this study. A total of 235 TB patients were recruited in six primary care clinics in the district of Kuching, Sarawak in Malaysia using convenience sampling method. A self-administered questionnaire, Patient Health Questionnaire-9 (PHQ-9), was used to screen for depression, and social support was accessed using Multidimensional Scale of Perceived Social Support, MSPSS. This study showed that the prevalence of depression among TB patients was 7.7\%. Socio-demographic factors, tuberculosis-related clinical data and social support are not significantly associated with participant's depressive states. Findings also showed that there is no different in terms of social support received by depressive and non-depressive tuberculosis patients. Conclusively, depression in TB patients is considered low; however, screening for depression in TB patients should not be neglected because it can lead to better treatment outcomes.
\end{abstract}

Keywords: Depression; prevalence; tuberculosis

ABSTRAK

Kemurungan dalam pesakit tuberkulosis meningkatkan risiko untuk penyusutan tahap kesihatan keseluruhan. Namun demikian, tidak banyak yang diketahui mengenai kemurungan dalam kalangan pesakit tuberkulosis di Malaysia. Kajian ini bertujuan untuk mengenal pasti kadar prevalens dan faktor berkaitan kemurungan dalam kalangan pesakit tuberkulosis pada peringkat kesihatan primer. Suatu kajian lintang yang melibatkan seramai 235 pesakit TB di enam buah klinik primer di Kuching, Sarawak telah dijalankan, menggunakan soal-selidik PHQ-9 (Soal Selidik Kesihatan Pesakit) bagi saringan kemurungan dan saringan Skala Pelbagai Dimensi Persepsi Sokongan Sosial (MSPSS) bagi mengenal pasti sokongan sosial pesakit. Kajian mendapati tahap kemurungan pesakit adalah tinggi sebanyak 7.7\%, dengan faktor sosio-demografi, keadaan klinikal dan sokongan sosial tidak berkait dengan tahap kemurungan. Kajian juga mendapati tiada perbezaan antara mereka dalam kemurungan dan tidak murung. Kesimpulannya, walaupun tahap kemurungan pesakit TB adalah rendah namun saringan berterusan adalah perlu bagi memastikan keberhasilan rawatan yang baik.

Kata kunci: Kemurungan; prevalens; tuberkulosis

\section{INTRODUCTION}

Tuberculosis (TB) is a contagious disease that remains as one of the public health burdens in Malaysia. World Health Organization (WHO) has estimated that approximately 6.3 million new cases of TB were diagnosed worldwide, with 1.3 million HIV-negative and 374000 HIV-positive patients succumbed from it in 2016 alone (WHO 2017). In Malaysia alone, it was reported that the incidence of TB was of 92 cases per 100,000 population in 2016 (WHO 2017). According to Bulletin Sector of Tuberculosis and Leprosy, Division of Disease Control of Malaysia Ministry of Health, Sarawak was noted to be the third- highest prevalence of TB cases, after Sabah and Selangor in 2017.

Depression is a known mental illness affecting approximately $10.3 \%$ of the Malaysia adult population (Siti Fatimah et al. 2014). There were several evidences showing the relationship between depression and chronic illness, including those with tuberculosis. Epidemiological studies have demonstrated higher prevalence of depression among TB patients in hospitalbased population with prevalence ranged from $43.4 \%$ to 56\% (Amreen \& Nadeem 2016; Duko et al. 2015; Xavier \& Peixoto 2015), as compared to community based 
population, which was $16.8 \%$ and $37 \%$, respectively (Masumoto et al. 2014; Ugarte-Gil et al. 2013). Whilst it is not clear of why depression occurred more in hospital settings, the prevalence showed that depression among TB patients is equally high to those with diabetes patients (40\%) (Sweileh et al. 2014), and hypertension (28.5\%) (Li et al. 2015).

Evidence showed that mortality and morbidity were higher in depression among TB patients (Ugarte-Gil et al. 2013) due to many reasons, but most notable was the non- adherence to TB treatment which resulted in multidrug resistance phenomenon (Aamir \& Aisha 2010; Theron et al. 2015). Among notable cause, depressive patients were usually lacking in self-care, motivation and feeling hopeless about themselves; hence, might have affected their attitude toward the TB regimes. Overall, depression among TB patients might be associated with treatment failure, poor outcome, and increase in TB burden.

This problem could be more relevant in the primary care setting, where the majority of TB patients are being managed as outpatient in which there is a risk for defaulting the medication and lack of monitoring at home. However, there is limited local study that explores the prevalence of depression in TB patients and its associated factors, more so in East Malaysia setting. Therefore, this study aimed to determine the prevalence and associated factors of depression amongst tuberculosis patients in primary care settings in Kuching District, Sarawak, Malaysia.

\section{MATERIALS AND METHODS}

A cross-sectional survey was carried out in six primary care clinics in the district of Kuching in Sarawak (Malaysia) from December 2017 to May 2018. A total of $235 \mathrm{~TB}$ patients were recruited using convenient sampling method. Eligible participants were recruited from those who were able to read and converse either in English or Malay language and were above 18 years old. Participants who were illiterate, critically ill and suffering from mental conditions that can compromise their ability to give informed consent and answer the question correctly, were excluded from the study.

A self-administered questionnaire in English or Malay version was given to all participants. It consisted of 4 sections in which section A assessed sociodemographic characteristics of the respondents; Section B consisted of nine items of Patient Health Questionnaire (PHQ-9) intended for screening and measuring the severity of depression, PHQ- 9 total scores ranged from 0 to 27 , and each item scored from 0 (not at all) to 3 (nearly every day). Depression was categorized as minimal (0$4)$, mild (5-9), moderate (10-14), moderately severe (1519), and severe depression (20-27) from the score. As there were no differences in sensitivity and specificity for cut-off points between $8-11$; hence, in our study, a cut- off point on a score of 10 and above were categorized as having depression (Manea et al. 2012). The PHQ-9 was reported of having good internal with Cronbach's alpha $=0.70$ (Sherina \& Arroll 2012). Section C consisted of The Multidimensional Scale of Perceived Social Support (MSPSS) was used in assessing social support from three sources, including Family, Friends, and a Significant Other (Zimet et al. 1988). MSPSS consisted of 12 items, with four items for each subscale of Family, Friends, and a Significant Other. Each of the 12 items was scored from 1 (very strongly disagree) to 7 (very strongly agree). The score ranged from 7 to 84 and higher scores of the 12 items reflected a high perceived social support. The MSPSS has been translated into different languages, including Malay language, with good internal consistency of Cronbach's alpha of $0.84-0.92$ ( $\mathrm{Ng}$ et al. 2010; Zimet et al. 1990). Section D assessed TB-related clinical data of participants, namely: Body mass index (BMI), type of tuberculosis (Pulmonary tuberculosis, PTB)/Extra-pulmonary tuberculosis (EPTB), treatment status (new case or retreatment) and treatment phase (intensive or maintenance. These data were collected from the participants' case notes.

A pilot testing was conducted on five participants in order to validate the questionnaires and to test on participant's understanding of questionnaire items as participants in the study population spoke in different languages and dialects. All TB patients who came for follow up at Pusat Rawatan 1, PR1 in the district of Kuching, Sarawak, were screened for their eligibility for the study. Those who fulfilled the criteria were invited to participate in the study and informed consent was obtained prior to the the study. The participants were given assurance of confidentiality of that their personal and medical information. Participants were given the questionnaire for them to complete during their visit and returned it to the researcher at the end of their visit. In order to avoid duplication of cases, the case note and treatment book was marked. Participants who were identified as having depression (of any stages) were then referred to the respective medical officer, who was in charge for further assessment and management.

Data were analysed using IBM SPSS Statistics Version 23.0. The categorical data were described using frequency and percentage, while numerical data were described using means (standard deviation) for normally distributed data and median (interquartile range) for not normally distributed data. Student's T-test analysis was used to determine whether there is significant means difference in social support received between depressive and non-depressive tuberculosis participants. Univariable analysis using simple logistic regression followed by multivariate analysis multiple logistic regression was applied to determine social demographic and tuberculosis-related factors that were associated with depression. P-value $<0.05$ was considered as statistically significant. 
This study was approved by the Research Ethics Committee of Universiti Kebangsaan Malaysia (code no: FF-2017-272) and Medical Research Ethics Committee of the Ministry of Health \{NMRR-17-902-34792 (IIR)\}.

\section{RESULTS AND DISCUSSION}

A flow chart study of participants was shown in Figure 1. Out of 260 registered TB patients, 250 TB participants were approached, with three of the participants were excluded due to illiterate $(n=2)$, and was a known case of depression $(n=1)$, leaving a total of 247 participants participated in the study (95\% coverage). Seven participants were further excluded from analysis as they did not complete the questionnaire, with five were found to be overlapped, making the response rate of $94 \%(n=235)$ for final analysis. The means age of the participants was $43.7 \pm$ 16.6 years. The majority of participants were male $(63 \%)$, Malays $(40.9 \%)$ and married $(62.1 \%)$. Detailed sociodemographic characteristics of participants are shown in Table 1 .

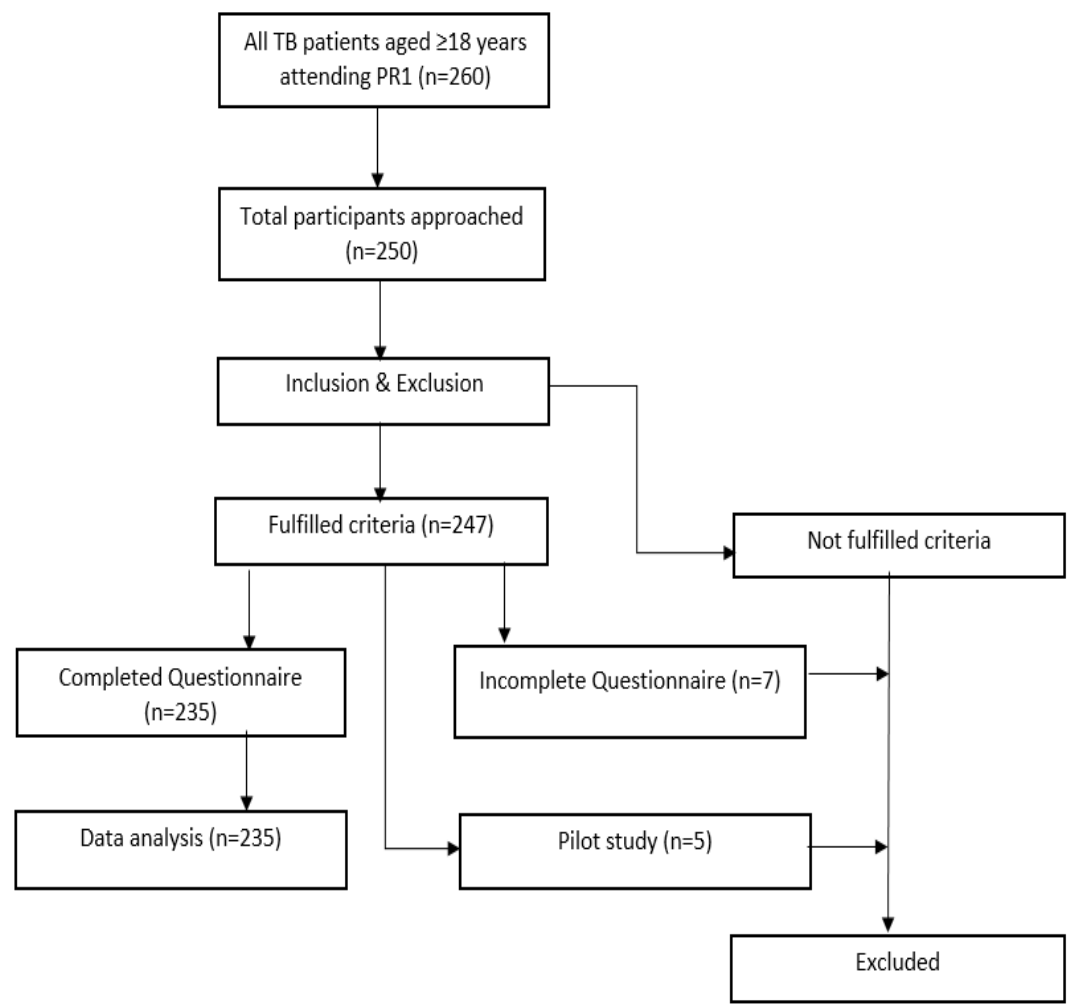

FIGURE 1. Flow chart study of participants

TABLE 1. Demographic characteristics of participants $(n=235)$

\begin{tabular}{lll}
\hline Characteristics & Means $\pm \mathrm{SD}^{\mathrm{a}}$ & $\mathrm{n}(\%)$ \\
\hline Age, years & $43.7 \pm 16.6$ & \\
$18-30$ & & $66(28.1)$ \\
$31-40$ & $47(20.0)$ \\
$41-50$ & $37(15.7)$ \\
$\geq 51$ & $85(36.2)$ \\
Gender & \\
Male & \\
Female & $148(63.0)$ \\
\end{tabular}




\begin{tabular}{|c|c|c|}
\hline \multicolumn{3}{|l|}{ Race } \\
\hline Malay & & $96(40.9)$ \\
\hline Chinese & & $63(26.8)$ \\
\hline Others & & $76(32.3)$ \\
\hline \multicolumn{3}{|l|}{ Marital Status } \\
\hline Single/ Divorced/ Widowed & & $89(37.9)$ \\
\hline Married & & $146(62.1)$ \\
\hline \multicolumn{3}{|l|}{ Education } \\
\hline Primary & & $72(30.6)$ \\
\hline Secondary & & $122(51.9)$ \\
\hline Diploma/Degree/Master & & $41(17.4)$ \\
\hline \multicolumn{3}{|l|}{ Employment } \\
\hline Employed & & $143(60.9)$ \\
\hline Unemployed & & $57(24.3)$ \\
\hline Retired & & $35(14.9)$ \\
\hline \multicolumn{3}{|l|}{ Income } \\
\hline$<\mathrm{RM} 2300$ & & $173(73.6)$ \\
\hline$\geq \mathrm{RM} 2300$ & & $62(26.4)$ \\
\hline \multicolumn{3}{|l|}{ Type of tuberculosis } \\
\hline Pulmonary & & $183(77.9)$ \\
\hline Extra pulmonary & & $53(26.4)$ \\
\hline \multicolumn{3}{|l|}{ Treatment status } \\
\hline New treatment & & $214(91.1)$ \\
\hline Retreatment & & $21(8.9)$ \\
\hline \multicolumn{3}{|l|}{ Treatment phase } \\
\hline Intensive & & $122(51.9)$ \\
\hline Maintenance & & $113(48.1)$ \\
\hline \multicolumn{3}{|l|}{ MSPSS } \\
\hline Total & $67.2(12.31)$ & \\
\hline Family & $24.0(4.32)$ & \\
\hline Friend & $20.1(5.43)$ & \\
\hline Significant Other & $23.1(5.22)$ & \\
\hline
\end{tabular}

Based on our assessment using PHQ-9 and with a cut-off point of 10 or more, it showed that $7.7 \%$ of the participants were categorized as depressive, whereas $92.3 \%$ of the participants were non-depressive (Table 2). Demographic factors of age, gender, race, marital status, education, employment, income, type of tuberculosis, and treatment status and treatment phase did not have any association with the depressive states of the TB patients. Simple logistic regression analysis showed that there was no risk factor that was significantly associated with the depressive state in TB patients (Table 3). There was also no significant difference in terms of social support received in depressed tuberculosis patients and non-depressed tuberculosis patients. There were no significant means difference in MSPSS total score among depressed 62.39 (12.82) and non-depressed TB patients $67.61(12.21)(\mathrm{p}$-value $=0.084)($ Table 4$)$. 
TABLE 2. Depressive state in tuberculosis patients $(n=235)$

\begin{tabular}{|c|c|c|c|}
\hline Depressive state & PHQ-9 score & Severity & n $(\%)$ \\
\hline \multirow[t]{2}{*}{ Non-depressive state } & $0-4$ & Minimal & $185(78.7)$ \\
\hline & $5-9$ & Mild & $32(13.6)$ \\
\hline \multirow[t]{3}{*}{ Depressive state } & $10-14$ & Moderate & $11(4.7)$ \\
\hline & $15-19$ & Moderate severe & $3(1.3)$ \\
\hline & $20-27$ & Severe & $4(1.7)$ \\
\hline
\end{tabular}

PHQ-9 = Patient Health Questionnaire-9

TABLE 3. Association of depressive state with demographic factors $(n=235)$

\begin{tabular}{|c|c|c|c|c|}
\hline \multirow[t]{2}{*}{ Variables } & \multirow[t]{2}{*}{ Crude OR } & \multicolumn{2}{|c|}{$95 \% \mathrm{CI}$} & \multirow[t]{2}{*}{$P$ value } \\
\hline & & Lower & Upper & \\
\hline \multicolumn{5}{|l|}{ Age } \\
\hline $18-30$ & 1.00 & & & \\
\hline $31-40$ & 3.07 & 0.73 & 12.98 & $0.127^{\mathrm{a}}$ \\
\hline $41-50$ & 1.20 & 0.19 & 7.53 & $0.846^{\mathrm{a}}$ \\
\hline$>51$ & 1.89 & 0.47 & 7.59 & $0.372^{\mathrm{a}}$ \\
\hline \multicolumn{5}{|l|}{ Gender } \\
\hline Male & 1.00 & & & \\
\hline Female & 1.09 & 0.41 & 2.92 & $0.864^{\mathrm{a}}$ \\
\hline \multicolumn{5}{|l|}{ Race } \\
\hline Malay & 1.00 & & & \\
\hline Chinese & 0.43 & 0.11 & 1.63 & $0.214^{\mathrm{a}}$ \\
\hline Others & 0.61 & 0.20 & 1.85 & $0.380^{\mathrm{a}}$ \\
\hline \multicolumn{5}{|l|}{ Marital Status } \\
\hline Married & 1.00 & & & \\
\hline Single/Divorced/Widowed & 1.71 & 0.65 & 4.49 & $0.274^{\mathrm{a}}$ \\
\hline \multicolumn{5}{|l|}{ Education } \\
\hline Diploma/Degree/ Master & 1.00 & & & \\
\hline Primary & 0.34 & 0.91 & 1.30 & $0.115^{\mathrm{a}}$ \\
\hline Secondary & 0.41 & 0.13 & 1.26 & $0.119^{\mathrm{a}}$ \\
\hline \multicolumn{5}{|l|}{ Employment } \\
\hline Employed & 1.00 & & & \\
\hline Unemployed & 2.36 & 0.81 & 6.85 & $0.114^{\mathrm{a}}$ \\
\hline Retired & 1.58 & 0.40 & 6.30 & $0.515^{\mathrm{a}}$ \\
\hline \multicolumn{5}{|l|}{ Income } \\
\hline$\geq \mathrm{RM} 2300$ & 1.00 & & & \\
\hline$<\mathrm{RM} 2300$ & 0.53 & 0.20 & 1.44 & $0.216^{\mathrm{a}}$ \\
\hline \multicolumn{5}{|l|}{ Type of tuberculosis } \\
\hline Pulmonary & 1.00 & & & \\
\hline Extra pulmonary & 1.40 & 0.47 & 4.10 & $0.549^{\mathrm{a}}$ \\
\hline \multicolumn{5}{|l|}{ Treatment status } \\
\hline New treatment & 1.00 & & & \\
\hline Retreatment & 3.36 & 1.00 & 11.35 & $0.051^{\mathrm{a}}$ \\
\hline \multicolumn{5}{|l|}{ Treatment phase } \\
\hline Maintenance & 1.00 & & & \\
\hline Intensive & 0.72 & 0.28 & 1.90 & $0.511^{\mathrm{a}}$ \\
\hline
\end{tabular}

${ }^{a}$ Significant at $\mathrm{p}<0.05$; OR, Odds Ratio; $95 \%$ CI, 95\% Confidence Interval 
TABLE 4. Comparison of the extent of social support received in depressed tuberculosis patients and non-depressed tuberculosis patients

\begin{tabular}{|c|c|c|c|c|c|c|}
\hline \multirow{2}{*}{ Variable } & \multicolumn{2}{|c|}{ Mean $(\mathrm{SD})^{\mathrm{a}}$} & \multirow{2}{*}{$\begin{array}{c}\text { Mean } \\
\text { Difference }\end{array}$} & \multirow[b]{2}{*}{$95 \% \mathrm{CI}$} & \multirow{2}{*}{$\begin{array}{l}\text { t statistic } \\
\text { (df) }\end{array}$} & \multirow[b]{2}{*}{$p$-value ${ }^{\mathrm{b}}$} \\
\hline & Depressed & Not Depressed & & & & \\
\hline Total MSPSS & $62.39(12.82)$ & $67.61(12.21)$ & 5.22 & $-0.70,11.14$ & $1.736(233)$ & 0.084 \\
\hline Family MSPSS & $22.39(5.08)$ & $24.16(4.23)$ & 1.77 & $-0.31,3.85$ & $1.68(233)$ & 0.095 \\
\hline Friend MSPSS & $18.11(4.51)$ & $20.28(5.48)$ & 2.17 & $-0.45,4.79$ & $1.63(233)$ & 0.104 \\
\hline $\begin{array}{l}\text { Significant other } \\
\text { MSPSS }\end{array}$ & $21.89(4.48)$ & 23.17 (5.27) & 1.28 & $-1.24,3.80$ & $1.00(233)$ & 0.318 \\
\hline
\end{tabular}

${ }^{\mathrm{a}}$ Standard deviation; ${ }^{\mathrm{b}}$ Independent T test; $95 \%$ CI, 95\% Confidence Interval; df, degrees of freedom; MSPSS, Multidimensional Scale of Perceived Social Support

This paper focused on the prevalence of depression in TB patients in the district of Kuching, Sarawak, which is one of the 13 states in Malaysia. Our study showed that $7.7 \%$ of $\mathrm{TB}$ patients receiving treatment in primary care clinics were depressed. The prevalence of depression in TB patients in our study is considered to be relatively low compared to previous studies conducted in other countries, namely Philippines (16.8\%, Masumoto et al. 2014), Peru (37\%, Ugarte-Gil et al. 2013), South Ethiopia (43.4\%, Duko et al. 2015), and Angola (49.4\%, Xavier \& Peixoto 2015). These variations could be due to factors such as the difference in study design, instruments, sample size, sampling method, and the participants themselves. For example, Ugarte-Gil in Peru used different assessment depression tools from our study; i.e. Center for Epidemiological Studies Depression Scale (CES-D) (Ugarte-Gil et al. 2013) which could explain the difference in prevalence of depression from our study.

Our findings also showed that socio-demographic factors, tuberculosis-related clinical data and social support received by TB patients were not significantly associated with depression. This differs from previous studies where socio-demographic factors such as age, gender, marital status, education level, and employment were positively associated with depression in TB patients (Kehbila et al. 2016; Ugarte-Gil et al. 2013). These studies also demonstrated the association of tuberculosis-related clinical data, including extrapulmonary tuberculosis (Xavier \& Peixoto 2015) and being on retreatment for tuberculosis (Kehbila et al. 2016), with depression in TB patients which were not found in our study.

The low prevalence of depression among TB patients in this present study is unique and surprising.
Although not being studied directly, we postulated that the low prevalence of depression could be brought about by patients' overall satisfaction with health services received together with good rapport established between patients and the clinic staffs during their TB treatment. Patients receiving TB treatment in government hospitals in Sarawak and Malaysia have relatively easy access to tuberculosis drugs, which are given free to the patients. Patients are also given easy access to the Family Medicine Specialists and doctors for management or counselling during their treatment period. Nonetheless, these data should be interpreted with caution due to small sample size and restricted locality of the study's site (Kuching).

Patients receiving tuberculosis medication were put on directly observed therapy (DOT) in which they need to come regularly to take their medication at the primary care clinic with the healthcare workers directly supervise them in taking the medication on a daily basis. Nonetheless, taking into account barriers such as distance, transportation and financial limitations, an innovation observing DOT was introduced in Sarawak by which the patients are given a choice to take their medication at the nearest clinic such as Klinik Kesihatan 1 Malaysia or placed under the supervision of trained non-healthcare worker such as village headman or family member. Apart from that, nongovernmental organizations, NGOs, also play an important role in supporting the local TB clinics, such as by providing enablers stipends for carfare to ensure compliance of the tuberculosis patients with financial problems coming to clinic for DOT. This measure is indirectly resulting in better adherence to treatment and higher likelihood of satisfaction of the treatment. 
Findings from this study also indicate that there is no difference in terms of social support received in both depressed and non-depressed TB patients. Our finding contradicts previous studies conducted in the Philippines and South Ethiopia, which highlighted that inadequate social support received by TB patients was significantly associated with depression (Duko et al. 2015; Masumoto et al. 2014). Our hypothesis of this contradictory finding could be due to the unique setup of the local family support group system, by which most of our participants are still living with extended family in a community long-houses accommodation. The interaction and the common living space might enable them to receive good moral and social support, thus preventing them from being depressed.

The strength of the study is that this is the first local study addressing depression among TB patients in East Malaysia. It is particularly important as the World Health Organization is aiming for $90 \%$ and $80 \%$ reduction in TB deaths and TB incidence, respectively, by 2030 (WHO 2017). An early detection of depression among tuberculosis patients might reduce the risk of TB's mortality.

Our results should be interpreted in light of several limitations. First, this study did not conduct a thorough exploration on the importance of risk factor associated with depression in TB patients, whereas some previous studies had included the impact of stigma using qualitative or mixed-methods (Baldwin et al. 2004; Duko et al. 2015; Kehbila et al. 2016; Rundi 2010). Second, although a cross-sectional study is a good method for the study of prevalence; but it is difficult to determine a temporal relationship between tuberculosis and depression using only this method of survey.

\section{CONCLUSION}

In conclusion, the prevalence of depression in $\mathrm{TB}$ patients was low as compared to other studies. There is also no significant association on demographic factors and social support received by TB patients, with their level of depressive states.

\section{ACKNOWLEDGEMENTS}

The researchers are grateful to the participants and staffs of Hospital Rajah Charles Brooke Memorial (RCBM), Klinik Kesihatan Batu Kawa, Klinik Kesihatan Jalan Masjid, Klinik Kesihatan Kota Sentosa, Klinik Kesihatan Petra Jaya and Klinik Tanah Puteh in Kuching Sarawak who helped and participated in this study. This research was conducted without any incentive grant.

\section{REFERENCES}

Aamir, S. \& Aisha, A. 2010. Co-morbid anxiety and depression among pulmonary tuberculosis patients. Journal of the College of Physicians and Surgeons Pakistan 20(10): 703704.
Amreen. \& Nadeem, R. 2016. Frequency of depression and anxiety among tuberculosis patients. Journal of Tuberculosis Research 4(4): 183-190.

Baldwin, M.R., Yori, P.P., Ford, C., Moored, D.A.J., Gilman, R.H., Vidal, C., Ticona, E. \& Evans, C.A. 2004. Tuberculosis and nutrition: Disease perceptions and health seeking behavior of household contacts in the Peruvian Amazon. International Journal of Tuberculosis and Lung Disease 8(12): 1484-1491.

Duko, B., Gebeyehu, A. \& Ayano, G. 2015. Prevalence and correlates of depression and anxiety among patients with tuberculosis at WolaitaSodo University Hospital and Sodo Health Center, WolaitaSodo, South Ethiopia, Cross sectional study. BMC Psychiatry 15(1): 1-7.

Kehbila, J., Ekabe, C.J., Aminde, L.N., Noubiap, J.J.N., Fon, P.N. \& Monekosso, G.L. 2016. Prevalence and correlates of depressive symptoms in adult patients with pulmonary tuberculosis in the Southwest Region of Cameroon. Infectious Diseases of Poverty 5(1): 51.

Li, Z., Li, Y., Chen, L., Chen, P. \& Hu, Y. 2015. Prevalence of depression in patients with hypertension. Medicine 94(31): e1317.

Manea, L., Gilbody, S. \& McMillan, D. 2012. Optimal cut-off score for diagnosing depression with the Patient Health Questionnaire (PHQ-9): A meta-analysis. Canadian Medical Association Journal 184(3): E191-E196.

Masumoto, S., Yamamoto, T., Ohkado, A., Yoshimatsu, S., Querri, A.G. \& Kamiya, Y. 2014. Prevalence and associated factors of depressive state among pulmonary tuberculosis patients in Manila, The Philippines. The International Journal of Tuberculosis and Lung Disease 18(2): 174-179.

Ng, C.G., Amer Siddiq, A.N., Aida, S.A., Zainal, N.Z. \& Koh, O.H. 2010. Validation of the Malay version of the Multidimensional Scale of Perceived Social Support (MSPSS-M) among a group of medical students in Faculty of Medicine, University Malaya. Asian Journal of Psychiatry 3(1): 3-6.

Rundi, C. 2010. Understanding tuberculosis: Perspectives and experiences of the people of Sabah, East Malaysia. Journal of Health, Population and Nutrition 28(2): 114-123.

Sherina, M.S. \& Arroll, B. 2012. Criterion validity of the PHQ-9 (Malay Version) in a primary care clinic in Malaysia. Med. J. Malaysia 67(3): 309-315.

Siti Fatimah Kader Maideen, Sherina Mohd. Sidik, Lekhraj Rampal \& Firdaus Mukhtar 2014. Prevalence, associated factors and predictors of depression among adults in the community of Selangor, Malaysia. PLoS ONE 9(4): e95395.

Sweileh, W.M., Abu-Hadeed, H.M., Al-Jabi, S.W. \& Zyoud, S.H. 2014. Prevalence of depression among people with type 2 diabetes mellitus: A cross sectional study in Palestine. BMC Public Health 14(1): 1-11.

Theron, G., Peter, J., Zijenah, L., Chanda, D., Mangu, C., Clowes, P. \& Rachow, A. 2015. Psychological distress and its relationship with non-adherence to TB treatment: A multicentre study. BMC Infectious Diseases 15: 253.

Ugarte-Gil, C., Ruiz, P., Zamudio, C., Canaza, L., Otero, L., Kruger, H. \& Seas, C. 2013. Association of major depressive episode with negative outcomes of tuberculosis treatment. PLoS ONE 8(7): 1-7.

World Health Organization (WHO). 2017. Global tuberculosis report 2017. http://www.who.int/tb/publications/global_ report/en/. 
Xavier, P.B. \& Peixoto, B. 2015. Emotional distress in angolan patients with several types of tuberculosis. African Health Sciences 15(2): 378-384.

Zimet, G.D., Powell, S.S., Farley, G.K., Werkman, S. \& Berkoff, K.A. 1990. Psychometric characteristics of the multidimensional scale of perceived social support. Journal of Personality Assessment 55(3-4): 610-617.

Zimet, G.D., Dahlem, N.W., Zimet, S.G. \& Farley, G.K. 1988. The multidimensional scale of perceived social support. Journal of Personality Assessment 52(1): 30-41.
Department of Family Medicine

Universiti Kebangsaan Malaysia Medical Centre

Jalan Yaacob Latif, Bandar Tun Razak

56000 Cheras, Kuala Lumpur, Federal Territory

Malaysia

*Corresponding author; email: azah@ppukm.ukm.edu.my

Received: 10 October 2019

Accepted: 14 January 2020 